\title{
Suitable climate for rubber trees affected by the South American Leaf Blight (SALB): Example for identification of escape zones in the Colombian middle Magdalena
}

\author{
Yeirme Jaimes ${ }^{\mathrm{a}, \mathrm{b}, \mathrm{d}}$, Jairo Rojas a, Christian Cilas ${ }^{\text {c, }}$, Edson L. Furtado ${ }^{\mathrm{d}, \mathrm{e}}$ \\ a Corpoica, Research Center La Suiza, Km 32 Vía al Mar, Rionegro-Santander, Colombia \\ ${ }^{\mathrm{b}}$ CAPES PEC-PG Fellow, Brazil \\ c CIRAD, UR Bioagresseurs, Campus de Baillarguet, TA A-106/D, 34398, Montpellier Cedex 5, France \\ d Plant Protection Department, Faculty of Agricultural Science, São Paulo State University, Botucatu, SP, Brazil \\ e CNPq Fellow, Brazil
}

\section{A R T I C L E I N F O}

\section{Article history:}

Received 28 August 2015

Received in revised form

20 December 2015

Accepted 21 December 2015

Available online 31 December 2015

\section{Keywords:}

Hevea brasiliensis

Pseudocercospora ulei

Zoning

Escape zones

\begin{abstract}
A B S T R A C T
South American Leaf Blight (SALB), caused by the fungus Pseudocercospora ulei, is the major constraint for rubber tree cultivation in Latin America, continent of origin of the rubber tree. The use of resistant tree cultivars and the identification of escape zones seem to be the best disease control measures. In order to characterize the climate and the pedological parameters in the region of Middle Magdalena, Colombia, we used temperature, relative humidity and annual rainfall records for a 20-year period (1990-2010) from 19 weather stations distributed across the region, together with definitions of the soil units for the area. With the recorded data, we calculated annual and monthly averages of temperature and relative humidity, annual rainfall, annual water balance, annual potential evapotranspiration, number of months with rainfall lower than $50 \mathrm{~mm}$ and $100 \mathrm{~mm}$, and number of months with relative humidity lower than $75 \%$. To determine the suitable climate for the rubber crop facing SALB, these results were interpolated through Inverse Distance Weighting with the software ArcGis 9.3 for each variable and their combinations, having as references the plant requirements and the disease escape areas. Regarding the annual rubber tree evapotranspiration requirement, the map showed that the region of Middle Magdalena is suitable for the rubber cultivation. However, La Gloria (Cesar), Regidor (Bolívar) and Gamarra (Cesar) are not suitable for rubber cultivation owing to the high soil hydric deficit $(>500 \mathrm{~mm})$. When we considered the rubber tree's requirements, the region was divided into the following types of areas: two unsuitable, two marginal and one suitable. However, considering the disease escape requirements, this region was divided into one unrestricted area and six preferential areas with different restrictions to the SALB control. The most important area of the Middle Magdalena Region is not an escape zone, hence in these areas, the use of highly productive clones resistant to $P$. ulei is suggested.
\end{abstract}

() 2015 Elsevier Ltd. All rights reserved.

\section{Introduction}

The South American Leaf Blight (SALB), caused by the fungus Pseudocercospora ulei, -formerly Microcyclus ulei- (da Hora et al., 2014), is the most destructive disease of the rubber tree (Hevea brasiliensis Muell. Arg.) in Latin America (Rivano et al., 2010). On susceptible cultivars, infected leaves fall and are replaced within a few weeks by new ones that can also succumb to SALB attacks. The

\footnotetext{
* Corresponding author.

E-mail address: christian.cilas@cirad.fr (C. Cilas).
}

most susceptible trees may consequently die from exhaustion as a result of repeated defoliation. Chemical control of SALB is technically feasible, but it is neither economically profitable nor ecologically desirable. The use of resistant and high-yielding rubber tree cultivars seems to be the best way to increase natural rubber production in South and Central America, as well as to anticipate an accidental introduction of SALB in Africa or Southeast Asia (Le Guen et al., 2011). The SALB fungus has a strong evolutionary potential (Barrès et al., 2012) and justifies the effort toward the development of a durable strategy to control this disease.

The identification of zones favorable for Hevea cultivation but unfavorable for the fungus' development (hereafter referred to as 
escape zones) could be a useful alternative to manage the disease. To identify escape zones, the annual water balance, relative humidity and dry season rainfall must be considered (Ortolani, 1986). The dry season is considered the most important season because it corresponds to the period of defoliation and refoliation of the rubber trees, and during this time, the plants are susceptible to the pathogen due to the presence of young leaves (Gasparotto et al., 2012). The elaboration of suitable climatic maps, known as zoning, would therefore be considered an important tool to give practical, logical and coherent recommendations for the disease management. These maps could serve as the basis to define the policies of the agriculture sector (da Silva et al., 2013). To achieve this, in the SALB escape zone studies the annual average temperature, true evapotranspiration, water deficit, as well as the altitude and pedological suitability of the area are considered.

The annual average temperature of $20{ }^{\circ} \mathrm{C}$ has been adopted as the tolerable lower limit for the rubber tree (Zong and Xuequim, 1983). For the bordering (frost-free) tropical regions, this corresponds to climatic conditions with seasonal temperature intervals for good growth and latex production (da Silva, 2007). Due to its origin in tropical and equatorial regions where it receives cold air streams coming from polar regions, the rubber tree can withstand low temperatures; hence the reason it has managed to successfully develop in subtropical regions (de Camargo and de Camargo, 2008). Concerning its true annual evapotranspiration, this is equal to $900 \mathrm{~mm}$, which corresponds to an annual average temperature of $20{ }^{\circ} \mathrm{C}$ (Zong and Xuequim, 1983). Zong and Xuequim (1983) observed that respiration rate exceeds the photosynthetic rate in conditions with temperatures higher than $40{ }^{\circ} \mathrm{C}$. For this reason, the thermic limits favoring photosynthesis lie between 27 and $30^{\circ} \mathrm{C}$, but the range of $18-28^{\circ} \mathrm{C}$ is more frequently cited because it favors latex flow (Ortolani, 1986).

As for P. ulei, more spores are produced between 23 and $25^{\circ} \mathrm{C}$, although sporulation can occur below $20^{\circ} \mathrm{C}$ with variable intensity depending on the clone-isolate combination. As a result, the annual average temperature is often one of the criteria considered as a limiting factor in the development of this pathogen (da Silva, 2007). The annual water deficit is also considered as an important factor in the SALB escape zones. The limit is considered to be $300 \mathrm{~mm}$ and considering the root depth that allows tolerance of dry periods, it could be greater than that (Ortolani, 1986). The greater the amount and the longer the duration of the water film on the rubber foliage, the higher the spores' probability of penetrating the leaf tissue (de Camargo and de Camargo, 2008). Concerning the humidity levels, SALB development requires $6 \mathrm{~h}$ of dew formation (da Silva, 2007). When the relative humidity is higher than $95 \%$, the disease incidence increases considerably. High disease incidence can also happen when there is abundant dew formation in areas with depressions or poorly drained slopes (de Camargo and de Camargo, 2008).

The Colombian Middle Magdalena region corresponds to the Inter Andean valley of the Magdalena river between the Honda currents and the Caribbean coastal plains (Fig. 1). The importance of the Middle Magdalena region is its strategic location for latex

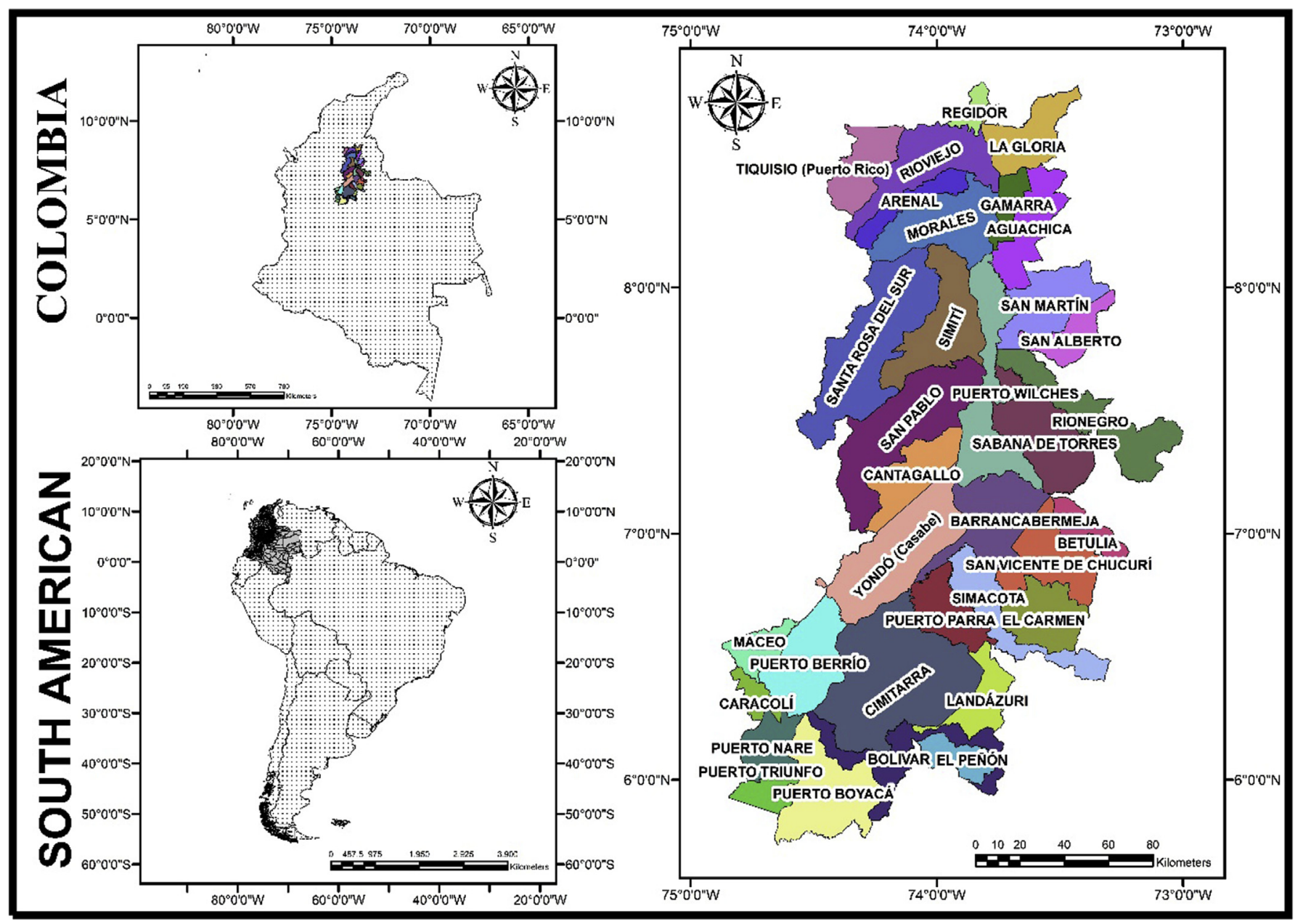

Fig. 1. Study area - Colombian Middle Magdalena. 
Table 1

Rubber tree climatic and pedological requirements (Hevea sp.).

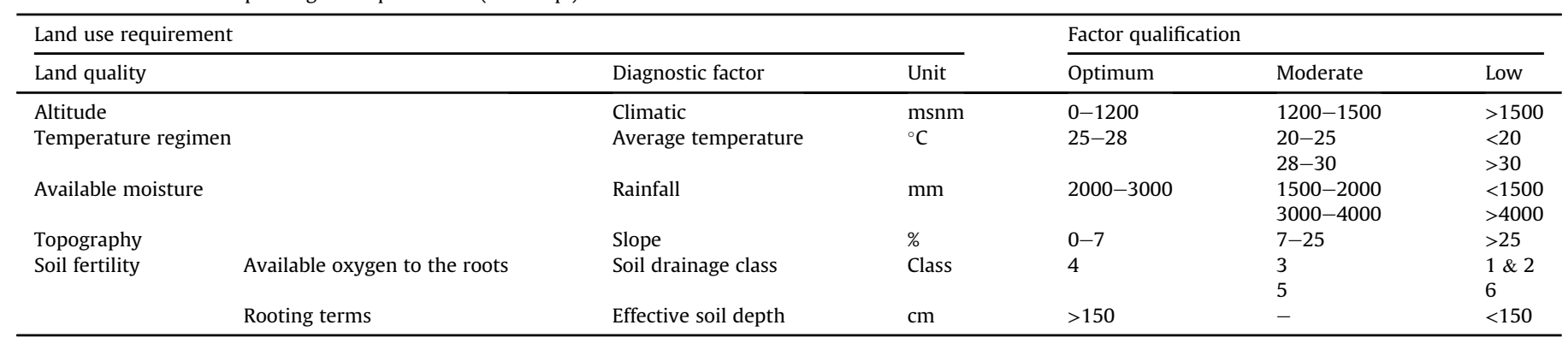

exports, i.e. very close to the seaport by roads and river. In the present work, the climate suitability maps of the Colombian Middle Magdalena region were drawn, taking into account the pedological and climatic suitability of the area for rubber tree cultivation, for the disease and for use as escape zones. In this way, this region was (a) divided into suitable, marginally suitable and unsuitable areas for Hevea cultivation and (b) escape zones were identified.

\section{Materials and methods}

In order to characterize the climatic and pedological suitability of the Colombian Middle Magdalena region, monthly records on wind, average temperature, relative humidity and rainfall from 1990 to 2010 were sourced from the 19 meteorological stations of the Colombian Hydrology, Meteorology and Environment Studies Institute (IDEAM). The water balance was calculated using the Thornthwaite and Mather (1955) method, adopting $150 \mathrm{~mm}$ as the maximum soil water holding capacity. The potential evapotranspiration was calculated by the Thornthwaite (1948) method developed for wet weather. Water balance and potential evapotranspiration were calculated based on the geographical coordinates and the wind temperature (Campanharo et al., 2011).

Subsequently, by comparison between soil and climate requirements of the rubber tree, we established suitability classes for Hevea cultivation (Table 1). We used also the climate information for the determination of SALB escape zones (Table 2). Climate data on average temperature, rainfall, true evapotranspiration, water deficit, number of months with rainfall less than $100 \mathrm{~mm}$ and $50 \mathrm{~mm}$, and number of months with relative humidity less than $75 \%$ were calculated. The variables and their combinations of data were interpolated using the deterministic method, Inverse Distance Weighting. This procedure was done using ArcGis 9.3 software with point values that were established by a linear combination of the known values (19 IDEAM meteorological stations). The layers obtained for each variable were used to generate the suitability maps: a) rainfall, temperature, evapotranspiration, water deficit, altitude, drainage, effective soil depth and rubber tree requirements (Table 1); b) months with rainfall less than $100 \mathrm{~mm}$ and $50 \mathrm{~mm}$, driest month's relative humidity, number of months with less than
$70 \%$ of relative humidity, number of dry months and annual water deficit requirements to SALB escape zone (Table 2).

To obtain the Colombian Middle Magdalena climatic suitability map for the rubber tree development, the rainfall, temperature, evapotranspiration and water deficit layers were transformed to raster and the contour of each zone was defined with the mask extraction tool using ArcGis 9.3 software. Then, the layers were overlaid to obtain the climatic suitability layer, and each zone identified using the ArcGis reclassify tool. The zones were classified as: - Unsuitable when one or more climatic zone conditions are unsuitable to rubber tree development; - Marginal when one or more climatic zone conditions are moderately suitable to rubber tree development; and - Optimum when all climatic zone conditions are suitable to rubber tree development.

We transformed to raster the Colombian Middle Magdalena region's suitability to the SALB escape zone map, months with rainfall less than $100 \mathrm{~mm}$ and $50 \mathrm{~mm}$, driest month's relative humidity, number of months with less than $70 \%$ of relative humidity, number of dry months and annual water deficit layer. The contour of each zone was defined with the mask extraction tool using ArcGis 9.3 software. Then, the layers were overlaid to obtain the climatic suitability layer, and each zone was identified using the reclassify tool using ArcGis 9.3 software. The zones were classified as: - With restriction when one or more climatic variables are suitable to SALB disease incidence; - Preferential with restriction when one or more climatic variables are moderately suitable to SALB disease incidence; and - Without restriction when all climatic zone conditions were unsuitable to SALB disease incidence.

\section{Results and discussion}

\subsection{Suitable areas of rubber tree cultivation}

With respect to the annual rainfall and average temperature requirements of the rubber tree, most areas of the Middle Magdalena have an optimum suitability (Figs. 2 and 3). If we considered only the rainfall, the region has fewer areas with moderate and low suitability. The red area is not suited to rubber tree development. In fact, the southwest of La Gloria (Cesar), southeast of Rioviejo

Table 2

SALB escape area requirements (Ortolani et al., 1983).

\begin{tabular}{|c|c|c|c|c|c|}
\hline \multicolumn{2}{|c|}{ Land use requirement } & \multicolumn{4}{|c|}{ Factor qualification } \\
\hline Land quality & Diagnostic factor & Unit & Optimum & Moderate & Low \\
\hline \multirow[t]{2}{*}{ Dry station } & Dry months (rainfall <100 mm) & \# months & $4-6$ & $3-4$ & $>3$ \\
\hline & Driest months (rainfall $<50 \mathrm{~mm}$ ) & \# months & $3-4$ & $1-2$ & $0-1$ \\
\hline \multirow[t]{3}{*}{ Relative moisture } & Dry months & $\%$ & $<75$ & $75-80$ & $>80$ \\
\hline & Driest month & $\%$ & $<70$ & $70-80$ & $>80$ \\
\hline & Months with $\mathrm{RM}<75$ & \# months & 2 & 1 & 0 \\
\hline Water availability & Water deficit & $\mathrm{mm}$ & $>200$ & $100-200$ & $<100$ \\
\hline
\end{tabular}




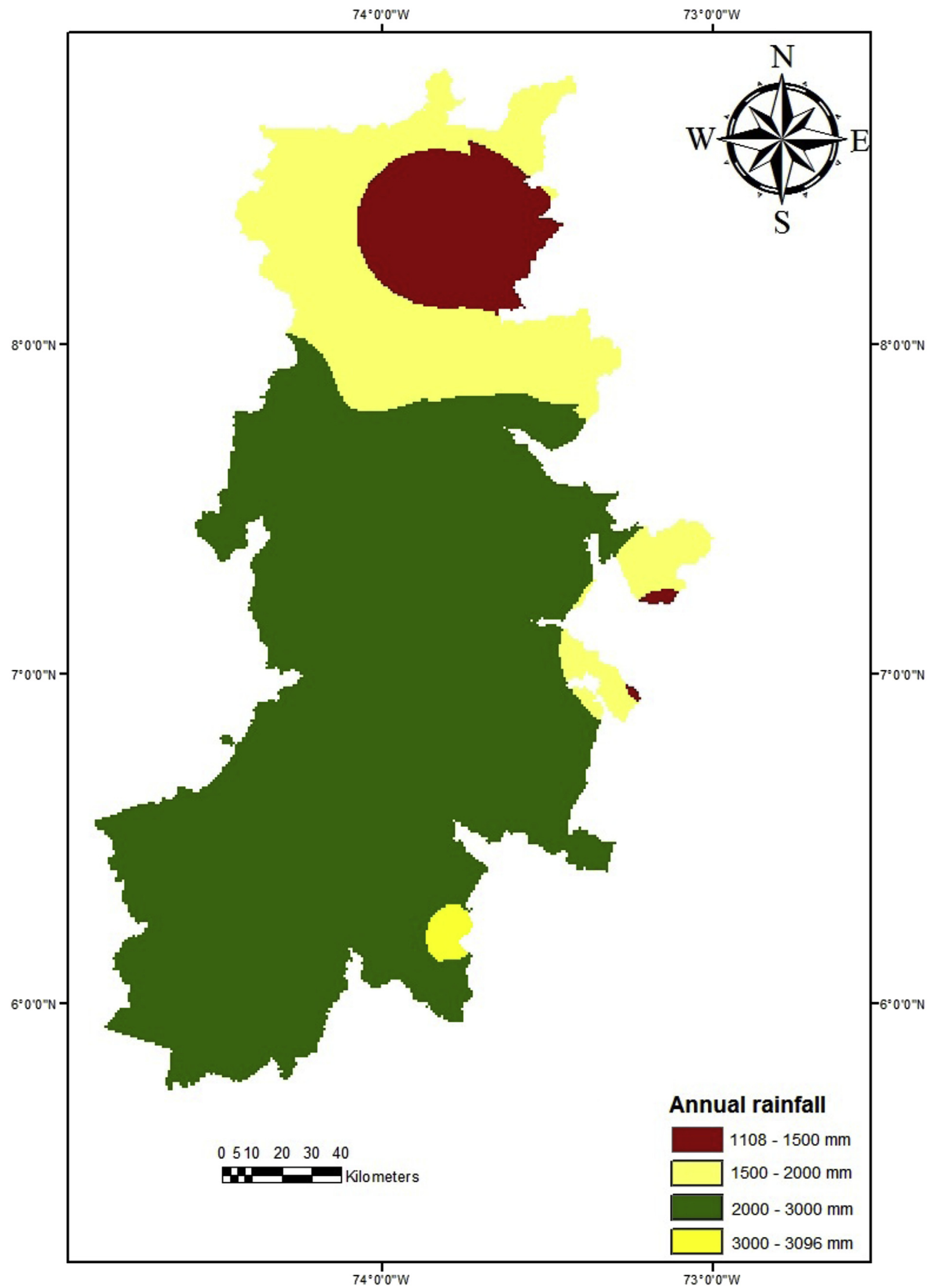

Fig. 2. Colombian Middle Magdalena zoned in low (red), moderate (yellow) and optimum (green) suitable areas by the rubber tree's rainfall requirement. 


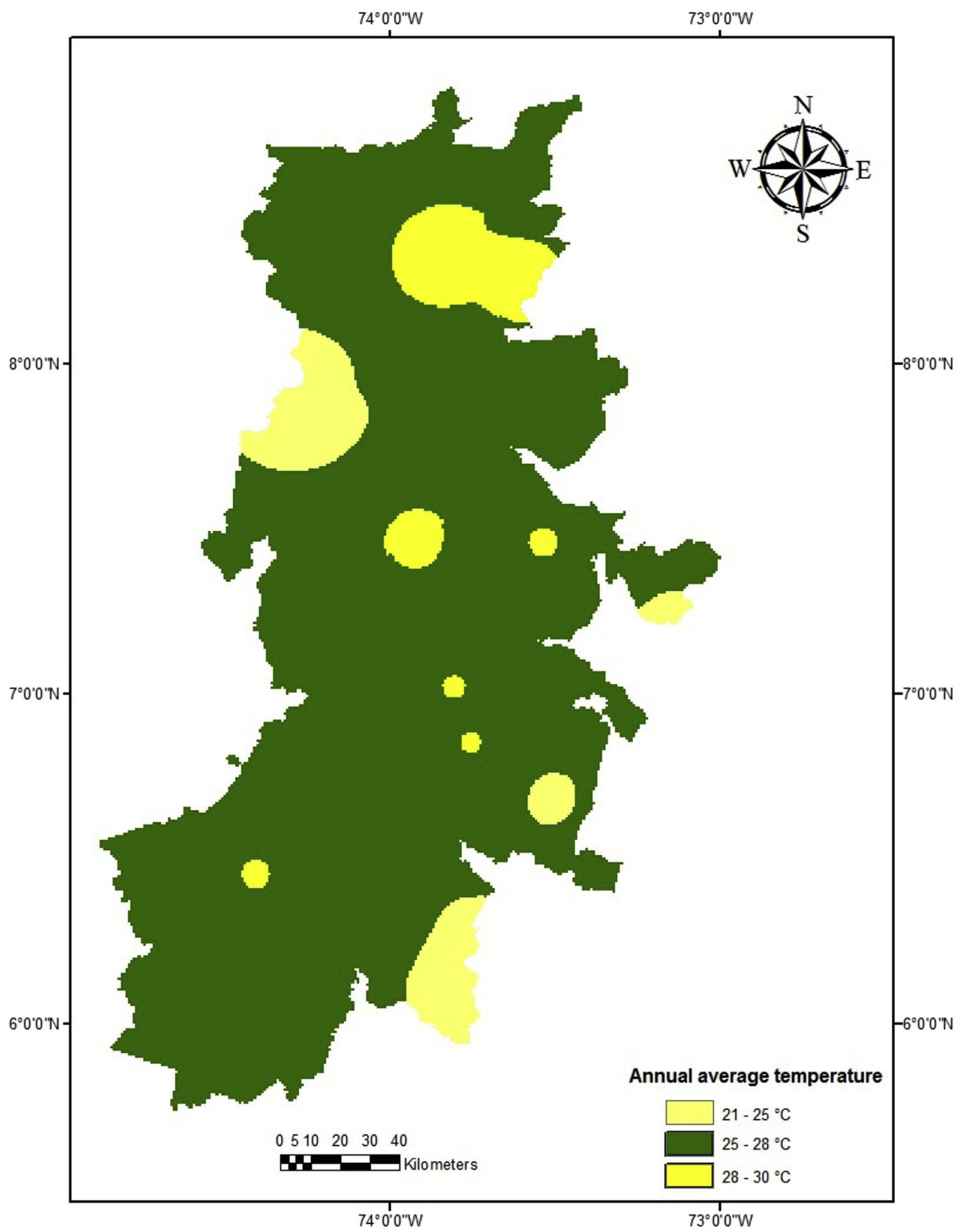

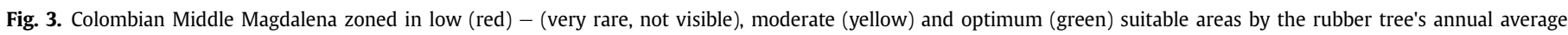
temperature requirement.

(Bolívar), a large area of the Arenal and Morales (Bolívar), Aguachica (Cesar) and Gamarra (Cesar), and a smaller area south of the Rionegro (Santander) and north of Betulia (Santander) are not recommended for rubber establishment.
Concerning the annual potential evapotranspiration, the entire Middle Magdalena region provides optimum conditions suited to rubber cultivation. However, when considering the water deficit variable for rubber cultivation, the entire area of the municipalities 
of La Gloria (Cesar), Regidor (Bolívar) and Gamarra (Cesar) is not suited for rubber cultivation due to the elevated soil water deficit (>500 mm) (Fig. 4). The municipalities of Rioviejo (Bolívar), Tiquisio (Bolívar), Arenal (Bolívar), Morales (Bolívar) and San Martin (Cesar) have marginally unsuitable zones since their soil water deficits range between 300 and $500 \mathrm{~mm}$. Santa Rosa del Sur (Bolívar), Símiti (Bolívar) and Puerto Wilchez (Santander) municipalities have smaller areas of marginal suitability. The other 22 municipalities and to a small extent San Alberto have areas suited to rubber tree development. It is important to mention that the rubber tree's tolerance to high water deficits (at times annually up to $300 \mathrm{~mm}$ ) occurs when the regions have deep soils (de Camargo and de Camargo, 2008).

Once the Middle Magdalena region was classified according its suitability for each variable, the annual average temperature, annual water deficit and the temperature $\left(22-27.8{ }^{\circ} \mathrm{C}\right)$ of the coldest month of the year (October) layers were used to define the region climate suitability for rubber tree development. Note that this region does not have pronounced winters nor severe frosts. Using these layers, the region was divided into three unsuitable, one marginal, and one optimal zones as:

\subsubsection{Unsuitable zone 1}

Optimum annual temperature $\left(25-28{ }^{\circ} \mathrm{C}\right)$ and temperature of the coldest month $\left(>18{ }^{\circ} \mathrm{C}\right)$ conditions characterize it, but it has the longest dry periods. In this zone are the municipalities of La Gloria (Cesar) and Regidor (Bolívar), most of the Rioviejo area (Bolívar), Tíquisio (Bolívar) and Arenal (Bolívar), and in less of the Morales area (Bolívar), Gamarra (Cesar), Aguachica (Cesar), San Martín (Cesar), Puerto Wilchez (Santander) and Símiti (Bolívar), (Fig. 5).

\subsubsection{Unsuitable zone 2}

An optimum temperature of the coldest month $\left(>18^{\circ} \mathrm{C}\right)$, and moderate annual average temperature greater than $28{ }^{\circ} \mathrm{C}$ and low water deficit greater than $500 \mathrm{~mm}$ conditions characterize it. The high water deficit during the long dry periods is not suitable to the rubber trees. In this zone we find a large area of the municipalities Landazurí (Santander), El Peñon (Santander), and Santa Rosa del Sur (Bolívar), small areas of Rionegro (Santander), Sabana de Torres (Santander), El Carmen (Santander), Barrancabermeja (Santander), Simití (Bolívar) and Bolívar (Santander), and the limits between Puerto Wilchez (Santander), Cantagallo (Bolívar) and San Pablo (Bolívar); between Cimitarra (Santander) and Puerto Berrío (Antioquía); and between San Vicente de Chucurí (Santander), Simacota (Santander) and Barrancabermeja (Santander), (Fig. 5).

\subsubsection{Unsuitable zone 3}

An optimum temperature of the coldest month $\left(>18{ }^{\circ} \mathrm{C}\right)$, and moderate annual average temperature less than $25{ }^{\circ} \mathrm{C}$ and low water deficit greater than $500 \mathrm{~mm}$ conditions and very long dry periods characterize it. In this zone are the municipalities of Rioviejo (Bolívar), La Gloria (Cesar), Morales (Bolívar), Gamarra (Cesar) and Aguachica (Cesar), (Fig. 5).

\subsubsection{Marginal zone}

Optimum annual temperature $\left(25-28{ }^{\circ} \mathrm{C}\right)$, temperature of the coldest month $\left(>18{ }^{\circ} \mathrm{C}\right)$, and moderate water deficit between 300 and $500 \mathrm{~mm}$, but this has restricted soil depth. In this zone are the municipalities of Tíquisio (Bolívar), Rioviejo (Bolívar), Arenal (Bolívar), Morales (Bolívar), Simití (Bolívar), Puerto Wilchez (Santander), San Martín (Cesar) and San Alberto (Cesar), (Fig. 5).

\subsubsection{Optimum zone}

An optimum value of annual temperature $\left(25-28{ }^{\circ} \mathrm{C}\right)$, temperature of the coldest month $\left(>18{ }^{\circ} \mathrm{C}\right)$ and water deficit $(0-300 \mathrm{~mm})$ characterize it. In this zone, there are the municipalities of Puerto Boyacá (Boyacá), Puerto Triunfo (Antioquía), Puerto Naré (Antioquía), Caracolí (Antioquía), Bolívar (Santander), El Peñon (Santander), Landazurí (Santander), Cimitarra (Santander), Puerto Berrío (Antioquía), Maceo (Antioquía), Simacota (Santander), Puerto Parra (Santander), Barrancabermeja (Santander), Yondó (Antioquía), Cantagallo (Bolívar), San Pablo (Bolívar), Santa Rosa del Sur (Bolívar), Símiti (Bolívar), Puerto Wilchez (Santander), Sabana de Torres (Santander), Rionegro (Santander), San Vicente de Chucurí (Santander), Betulia (Santander), Sabana de Torres (Santander) and San Alberto (Cesar), (Fig. 5).

In terms of altitude, it was observed that most of the Middle Magdalena area provides optimum suitability for rubber tree cultivation. The east of Aguachica (Cesar), San Alberto (Cesar), San Martín (Cesar), El Carmen (Santander), San Vicente de Chucurí and Betulia (Santander); west of Rioviejo (Bolívar), Arenal (Bolívar), Morales (Bolívar) and Santa Rosa del Sur (Bolívar) and southeast of Rionegro (Santander) and Simacota (Santander) display low and moderate suitability for cultivation of this crop (Fig. 6).

Concerning the pedological suitability of the Colombian Middle Magdalena region, most of it possesses moderate conditions of drainage and soil depth (Figs. 7 and 8). Even if the same areas have optimum climatic conditions, the rubber tree establishment and development will still be restricted by the area's pedological condition given that the rubber tree requires deep, porous, well-drained and clayey soils with good moisture retention. Unsuitable soil conditions are considered limiting because the plant needs to remove large amounts of water for latex production [68\% water content] (do Carmo et al., 2004). For this reason, in zones with water deficits higher than $500 \mathrm{~mm}$ deep soils are required, and this does not exist in the northern zone of the Middle Magdalena region (Fig. 8).

The rubber tree has wide distribution of the root system, allowing exploration of a considerable soil volume. Usually, the suitable soils have an effective soil depth greater than $200 \mathrm{~cm}$, welldrained, with good permeability and porosity, among other attributes. It can be said that the climatic limitations can be managed if the crop is established in deep, permeable, sandy and clayey textured soil. It should be compacted clay, avoiding very sandy and stony soils that inhibit the expansion of the root system, especially in areas with a marked dry season (Pinheiro and Pinheiro, 2008).

\subsection{SALB escape zones}

Regarding the definition of the escape zones in the Colombian Middle Magdalena, we found that the north of San Martín (Cesar), Puerto Wilchez (Santander) and Simití (Bolivar), northeast of Tiquisio (Bolívar), great area of Morales (Bolívar), Arenal (Bolívar) and Rioviejo (Bolívar), the southeast of Rionegro (Santander), south of Betulia (Santander) and whole area of Gamarra (Cesar), Aguachica (Cesar), and La Gloria (Cesar) have a defined dry season characterized by 4-6 months of rainfall less than $100 \mathrm{~mm}$ (Fig. 9A). But, only the whole of Tiquisio (Bolívar), Morales (Bolivar), Arenal (Bolívar) and Rioviejo (Bolívar), the north of Santa Rosa del Sur (Bolívar), Puerto Wilchez (Santander) and San Alberto (Cesar), and the north and center of Simití (Bolívar) and San Martín (Cesar) have 3-4 months with rainfall less than $50 \mathrm{~mm}$ (Fig. 9B). For this reason, only in these latter-mentioned municipalities have escape zone conditions been fulfilled and considered as having optimum suitability for SALB escape.

Even though the north of Sabana de Torres (Santander) and Rionegro (Santander), the center of Puerto Wilchez (Santander), the south of San Alberto (Cesar), San Martín (Cesar) and Simití (Bolívar) and great area of Santa Rosa del Sur (Bolívar) and San Pablo (Bolívar) have a defined dry season characterized by 3-4 months of rainfall less than $100 \mathrm{~mm}$ (Fig. 9A), these have a moderate 


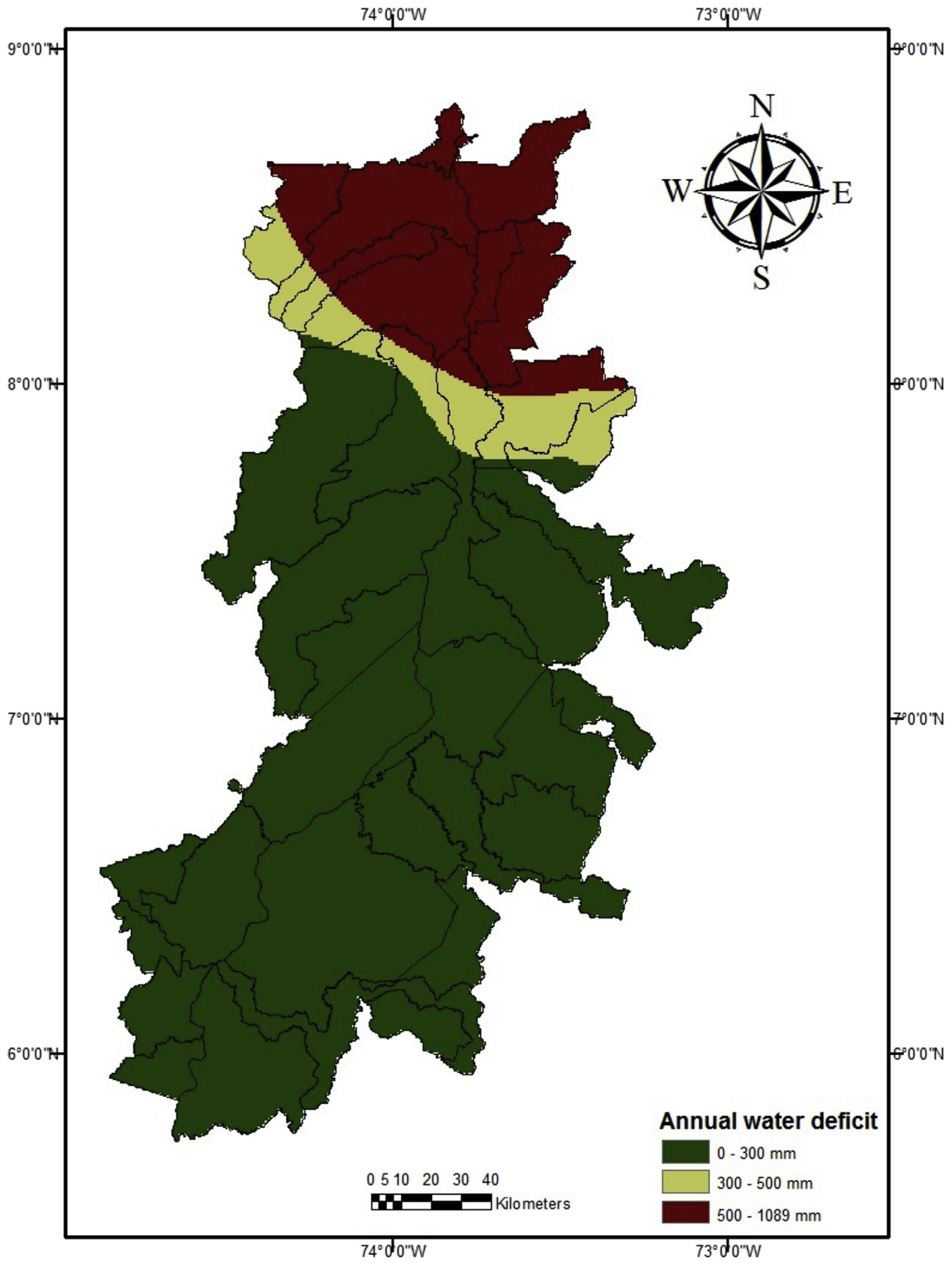

Fig. 4. Colombian Middle Magdalena zoned in low (red), moderate (yellow) and optimum (green) suitable areas by the rubber tree's annual water deficit requirement.

suitability because only $1-2$ months provide rainfall less than $50 \mathrm{~mm}$ (Fig. 9B). That means that these municipalities have preferential areas with restrictions. The other 20 municipalities located in the center and south of the Middle Magdalena are characterized as having rainfall over $100 \mathrm{~mm}$ during the year (Fig. 9A and B). These areas therefore have low suitability as SALB escape zones. 


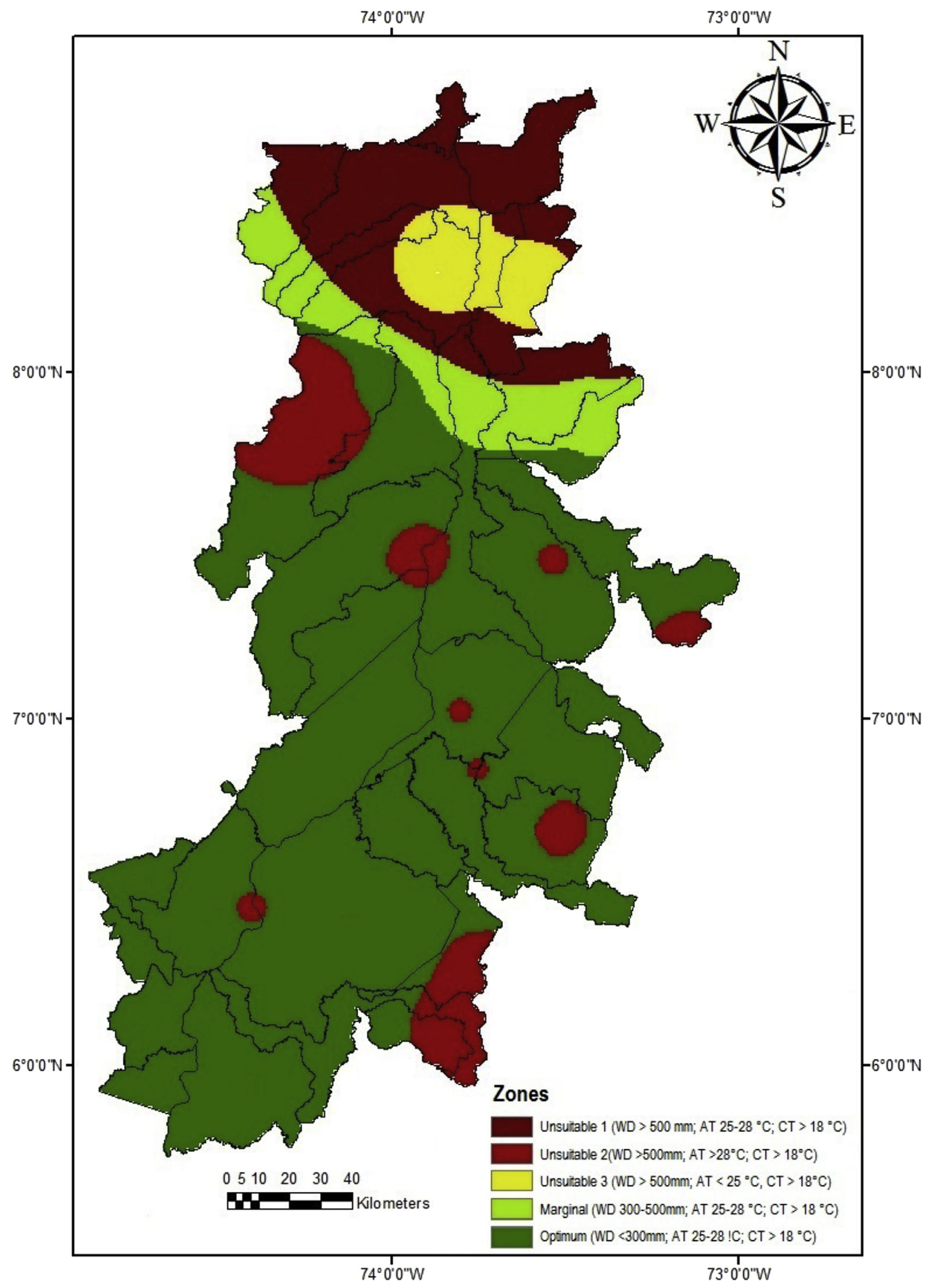

Fig. 5. Colombian Middle Magdalena climatic suitability map for rubber tree development. 


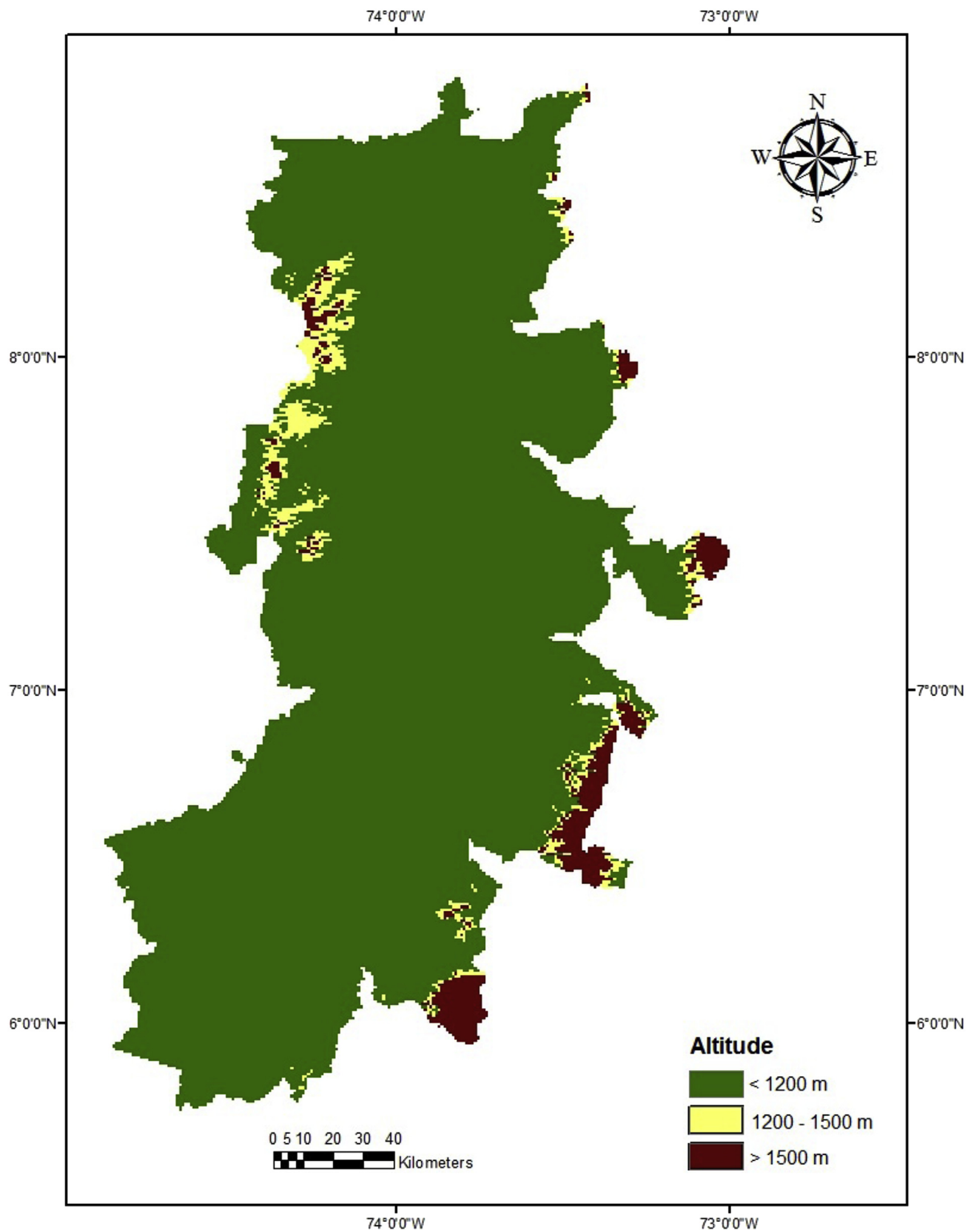

Fig. 6. Colombian Middle Magdalena zoned as low (red), moderate (yellow) and optimum (green) suitable areas by the rubber tree's altitude requirements.

Concerning the relative humidity for SALB escape zones, February is the driest month with values between $70 \%$ and $80 \%$ (Fig. 10A). Most areas in the region demonstrate this and so the area is of moderate suitability as an escape zone. Only the north part of the region has 2 months with relative humidity less than $75 \%$
(Fig. 10B and C). This condition allows these areas to be suitable as escape zones. These variables are considered important, because the humidity can facilitate foliar disease incidence inclusive of SALB. 


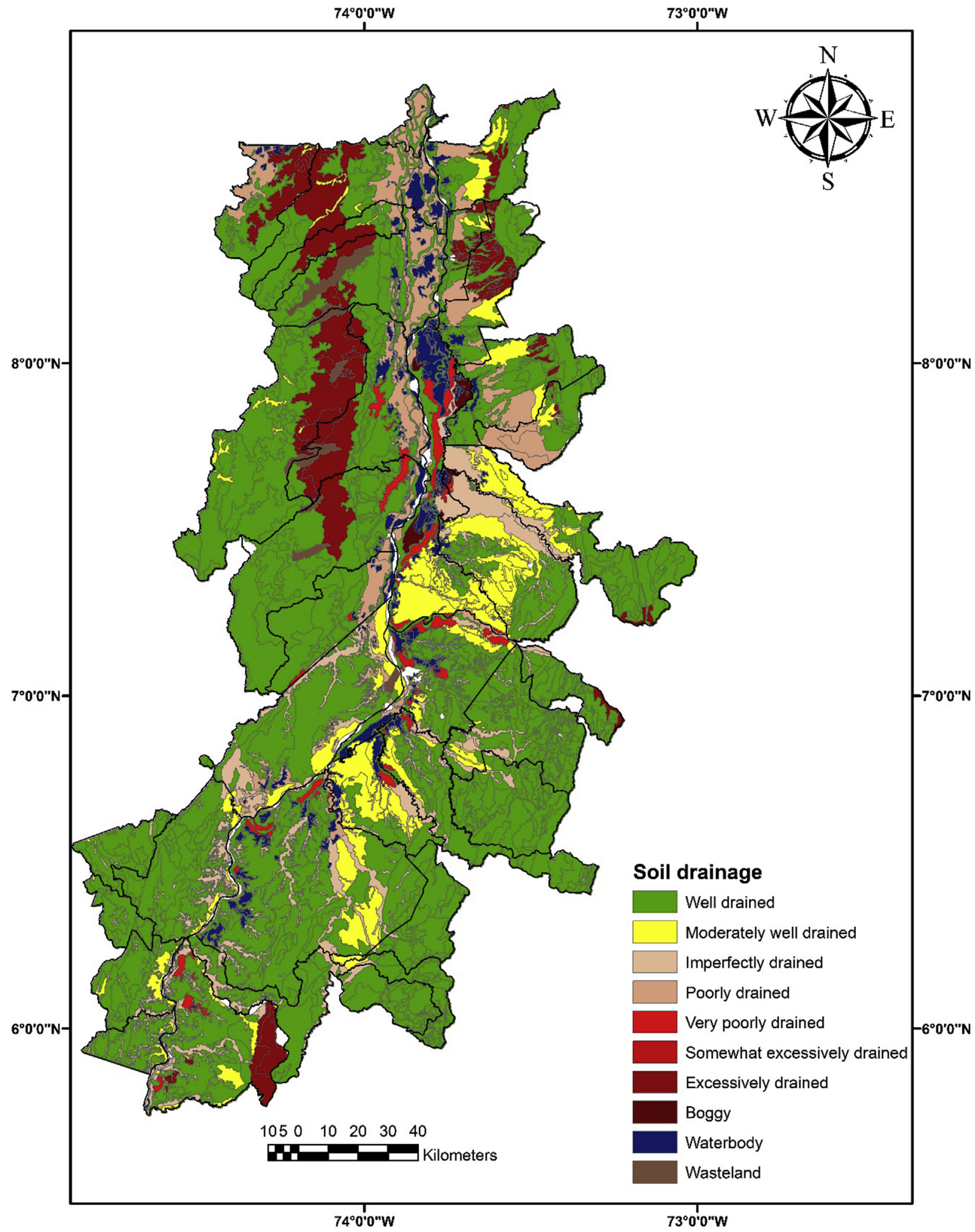

Fig. 7. Colombian Middle Magdalena zoned in low (red), moderate (yellow) and optimum (green) suitable areas by the rubber tree's drainage requirements.

3.3. Final zoning of the area by combining agronomic and epidemiological suitability

Once SALB escape zone suitability was defined for each variable, the Colombian Middle Magdalena region was zoned in accordance with the water deficit requirements (Fig. 11), annual evapotranspiration (EVT) and relative humidity of the driest month. These variables have also been employed by Ortolani et al. (1983) for defining SALB escape zones. With this, classification was as follows: 


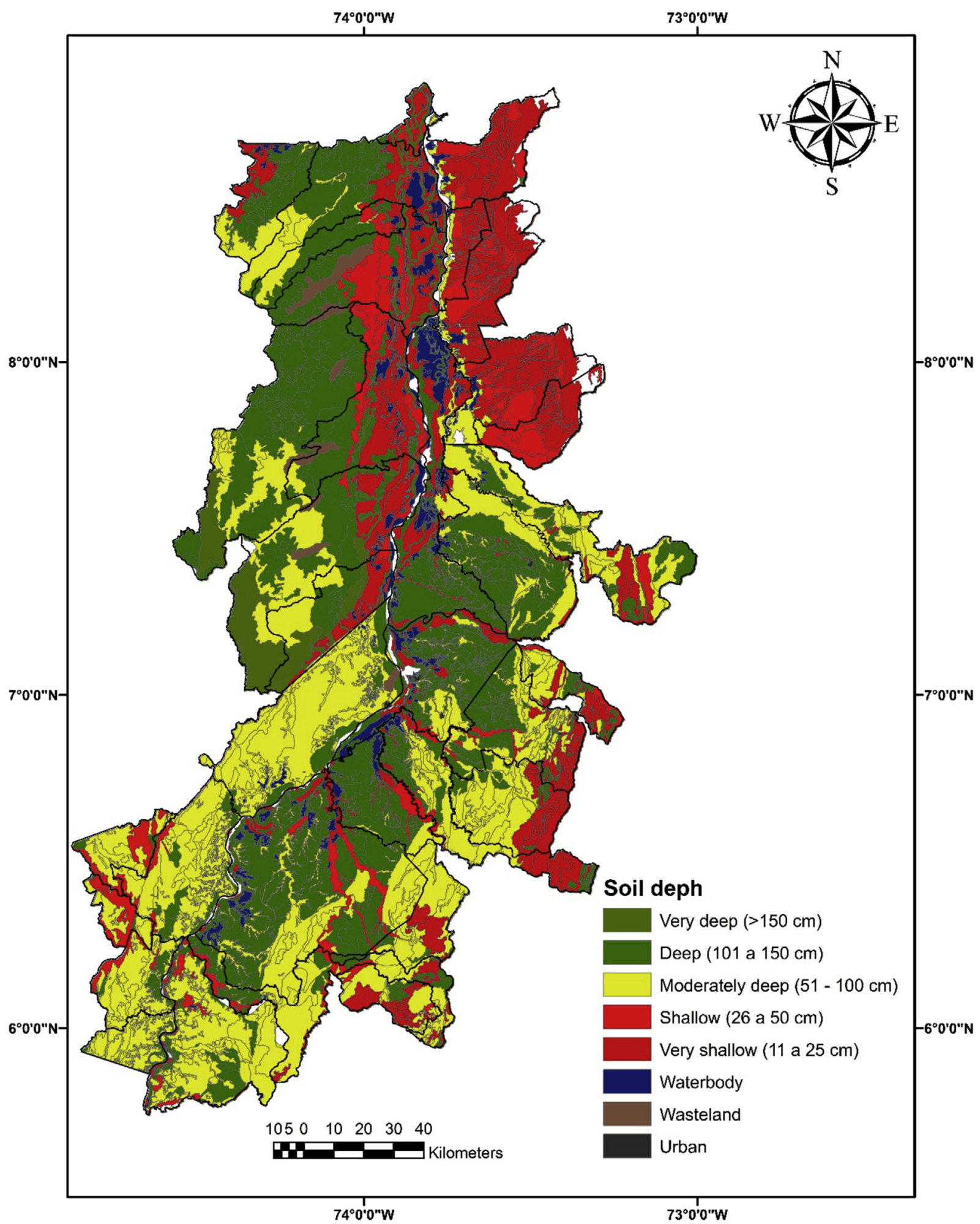

Fig. 8. Colombian Middle Magdalena zoned in low (red), moderate (yellow) and optimum (green) suitable areas by the rubber tree's soil depth requirements.

\subsubsection{Zone 1}

This zone presents no restriction to rubber tree growth. It has a water deficit greater than $300 \mathrm{~mm}$, evapotranspiration greater than $900 \mathrm{~mm}$ and relative humidity of the driest month less than 70\%. In this zone are La Gloria (Cesar), Regidor (Bolívar), Tíquisio (Bolívar), Gamarra (Cesar) and San Martín (Cesar), great area of Rioviejo (Bolívar), Arenal (Bolívar) and Morales (Bolívar), the north of Santa Rosa del Sur (Bolivar), northeast of Simití (Bolívar) and San Pablo (Bolívar), and the north and center of Puerto Wilchez (Santander) and San Alberto (Cesar), (Fig. 12). 

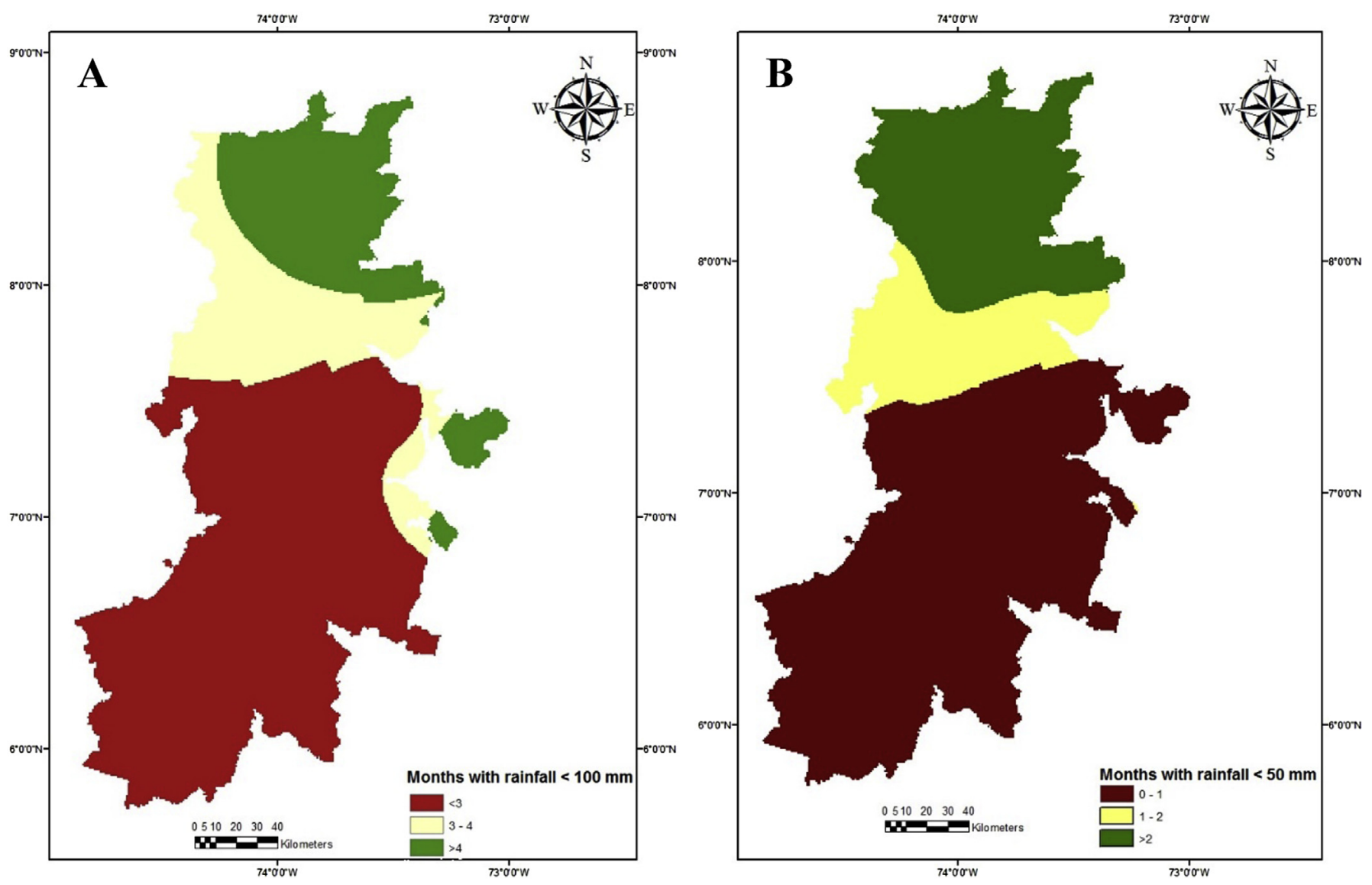

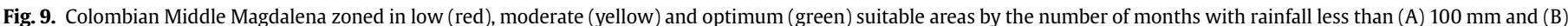
$<50 \mathrm{~mm}$ SALB escape zone requirements.

\subsubsection{Zone 2}

This zone is possible for rubber tree cultivation but with disease risk. It is characterized by having a water deficit greater than $300 \mathrm{~mm}$, evapotranspiration greater than $900 \mathrm{~mm}$ and relative humidity of the driest month between $70 \%$ and $80 \%$. In this zone are found small areas of the southeast of Rioviejo (Bolivar), Arenal (Bolívar) and Morales (Bolívar), the northeast and southeast of Santa Rosa del Sur (Bolívar), the southeast of Símiti (Bolívar) and Betulia (Santander), the west of San Pablo (Bolivar), the east of Puerto Wilchez (Santander), northwest of Sabana de Torres (Santander) and Rionegro (Santander) and south of San Alberto (Cesar), (Fig. 12).

\subsubsection{Zone 3}

This zone is also suitable, but with the restrictions of having a water deficit between 100 and $200 \mathrm{~mm}$, evapotranspiration greater than $900 \mathrm{~mm}$ and relative humidity of the driest month between $70 \%$ and $80 \%$. In this zone are found the entire area of Maceo (Antioquía), Puerto Berrío (Antioquía) and Caracolí (Antioquía), great area of Puerto Triunfo (Antioquía), Puerto Naré (Antioquía), Barrancabermeja (Santander), Rionegro (Santander) and Sabana de Torres (Santander), northeast of Yondó (Antioquía) and San Vicente de Chucurí (Santander), the west of Cimitarra (Santander), the center-south of Santa Rosa del Sur (Bolívar) and Cantagallo (Bolívar), southwest of San Pablo (Bolívar), the south of Puerto Wilchez (Santander), and the northwest and southwest of Betulia (Santander), (Fig. 12).

\subsubsection{Zone 4}

This zone is possible for rubber tree cultivation; it is characterized by having a water deficit between 100 and $200 \mathrm{~mm}$, evapotranspiration greater than $900 \mathrm{~mm}$ and relative humidity of the driest month less than 70\%. In this zone are found small areas of Santa Rosa del Sur (Bolívar) and Yondó (Antioquía), the center-east of Cantagallo (Bolívar), center-west of Puerto Wilchez (Santander) and Barrancabermeja (Santander) and the center of Betulia (Santander), (Fig. 12).

\subsubsection{Zone 5}

This zone is not really suitable for rubber tree cultivation; it is characterized as having a water deficit between 100 and $200 \mathrm{~mm}$, evapotranspiration greater than $900 \mathrm{~mm}$ and relative humidity of the driest month greater than $70 \%$. In this zone are the smaller areas of center-west of Santa Rosa del Sur (Bolívar), (Fig. 12).

\subsubsection{Zone 6}

Also, this zone is not really suitable for rubber tree cultivation; it is characterized as having a water deficit less than $100 \mathrm{~mm}$, evapotranspiration greater than $900 \mathrm{~mm}$ and relative humidity of the driest month greater than $80 \%$. In this zone are found the entire area of Landazurí (Santander) and El Peñon (Santander), great area of El Carmen (Santander) and Bolívar (Santander), the center of Santa Rosa del Sur (Bolívar), the southeast of Simacota (Santander), Cimitarra (Santander) and Puerto Boyacá (Boyacá) and small area of Puerto Parra (Santander) and San Vicente de Chucurí (Santander), (Fig. 12). 


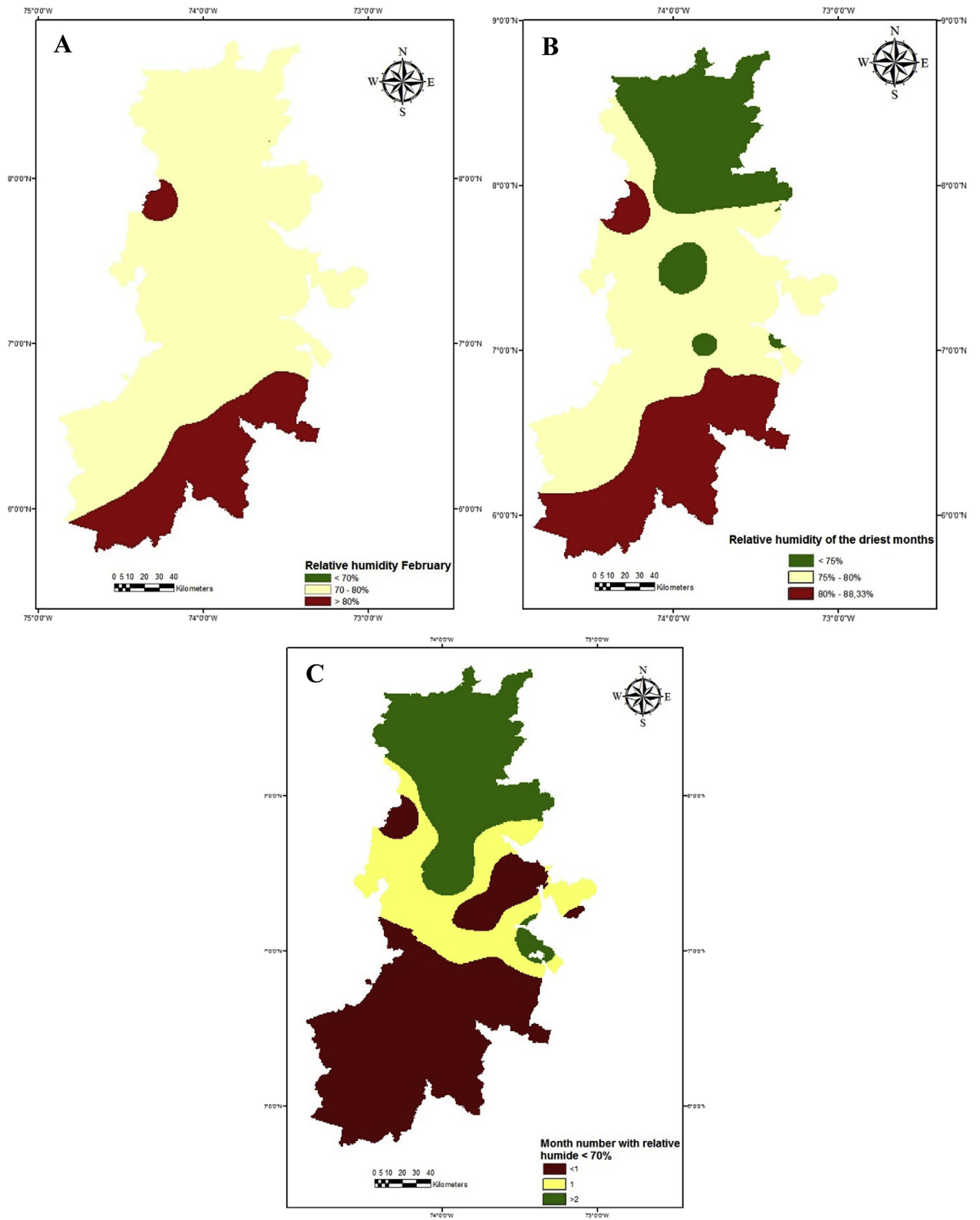

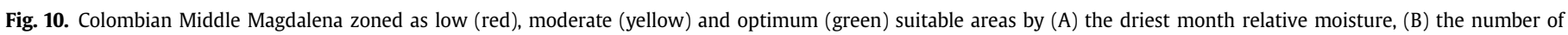
months with relative humidity less than $75 \%$, and (C) the number of dry months SALB escape zone requirements. 


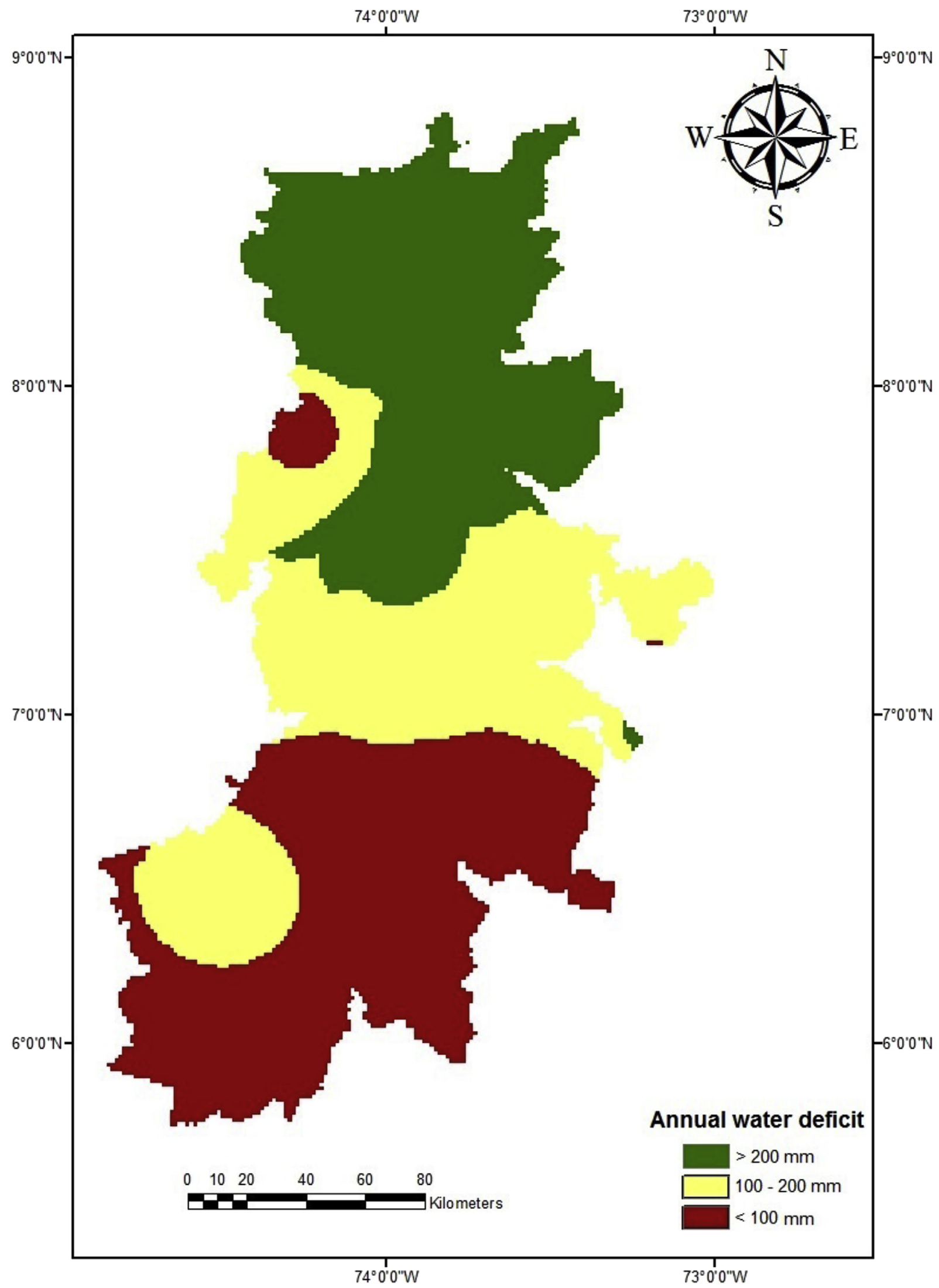

Fig. 11. Colombian Middle Magdalena zoned as low (red), moderate (yellow) and optimum (green) suitable areas by the annual water deficit SALB escape zone requirements. 


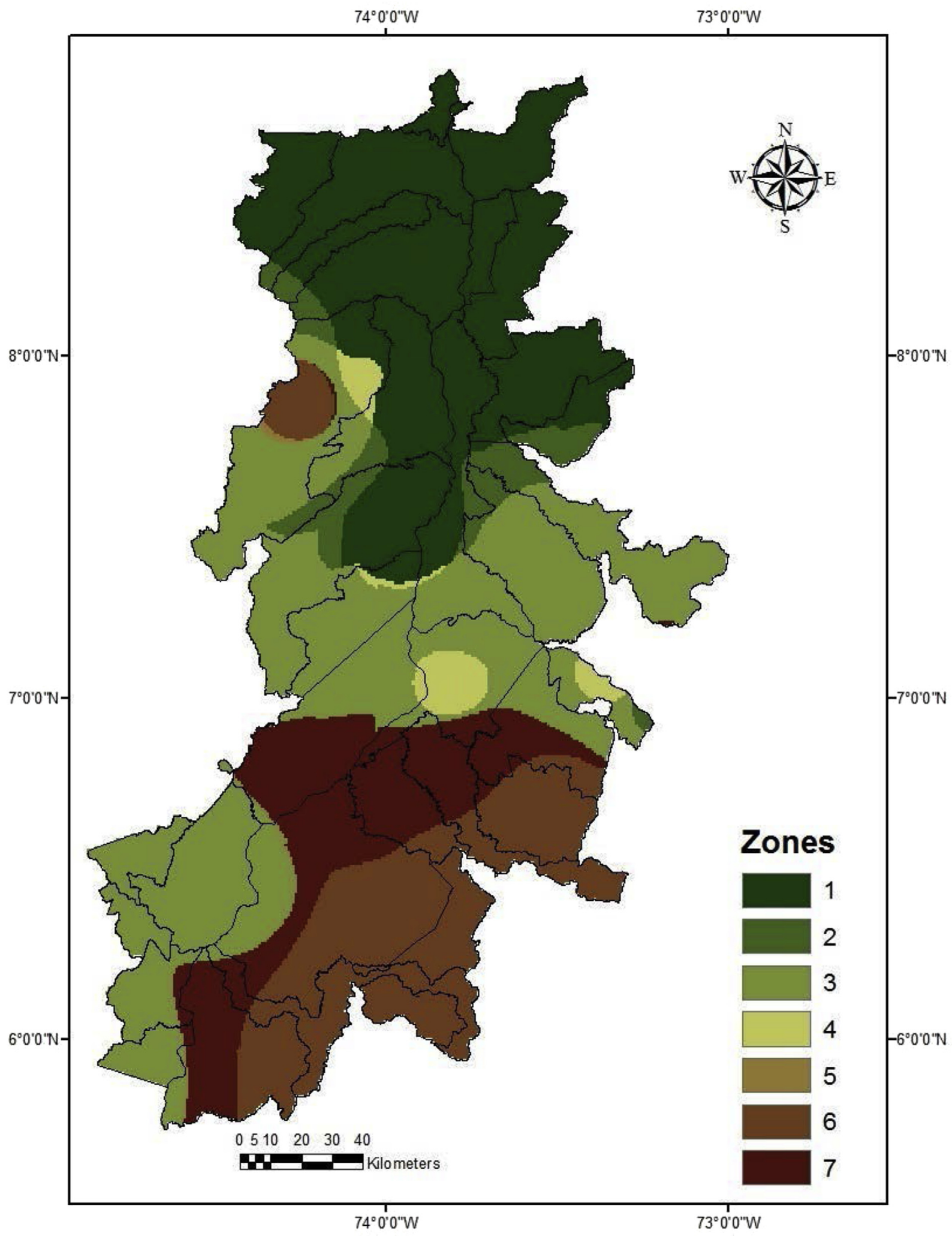

Fig. 12. Colombian Middle Magdalena suitability to the SALB escape zone.

\subsubsection{Zone 7}

This zone is possible for rubber tree cultivation; it is characterized as having a water deficit less than $100 \mathrm{~mm}$, evapotranspiration greater than $900 \mathrm{~mm}$ and relative humidity of the driest month between $70 \%$ and $80 \%$. In this zone are found the center of San Vicente de Chucurí (Santander), the north of Simacota (Santander) and Puerto Parra (Santander), the sur of Yondó (Antioquía), some area of Cimitarra (Santander) and Puerto Boyacá (Boyacá) and a 
smaller area of Santa Rosa del Sur (Bolívar), (Fig. 12).

With zoning of both crop and escape zone suitability, we observed that the zone with areas of climatic suitability for rubber tree cultivation (Fig. 5) coincides largely with the preferential zones for P. ulei (Fig. 12). This suggests that in these areas, clones resistant to $P$. ulei should be established.

With regard to the SALB unrestricted area (Fig. 12), rubber tree establishment would not be possible because this area exceeds the water deficit, i.e. greater than $500 \mathrm{~mm}$. Its condition is too dry and not suitable for rubber cultivation (Rivano et al., 2015). Moreover, this area has superficial and poorly drained soils. Hence, La Gloria (Cesar), Regidor (Bolívar), Rioviejo (Bolívar), Tíquisio (Bolívar), Arenal (Bolívar), Morales (Bolívar), Gamarra (Cesar) and Aguachica (Cesar) and small area of Morales (Bolívar), Gamarra (Cesar), Aguachica (Cesar), San Martín (Cesar), Puerto Wilchez (Santander) and Símiti (Bolivar) are unsuitable for rubber tree establishment.

With respect to marginal zone 1 (Fig. 5), for climate suitability, it demonstrates suitably well-drained soils. Some areas from this zone have this characteristic, thus they can be considered suitable for rubber establishment and as a SALB escape area. These areas are the southwest of Tíquisio (Bolívar), Rioviejo (Bolívar), Arenal (Bolívar) and Morales (Bolívar), (Fig. 7). Therefore, in these areas productive rubber tree clones can be cultivated without the requirement for them to be SALB resistant. For clonal recommendations, these areas should take into account local conditions to assess the phytosanitary risks SALB (Rivano et al., 2015).

\section{Conclusion}

Based on the study results, we identified that the center of Puerto Wilchez (Santander) - 21, northeast of San Pablo (Bolívar) 28 and the south of Símiti (Bolivar) have the optimum conditions of climatic, pedological and escape zone requirements for the rubber crop development. The northeast of the Middle Magdalena region is discarded, because it demonstrates only optimal conditions for an escape zone and not conditions suited to rubber tree development. The most optimally suited area for rubber cultivation presents, in large part, a preferential condition with restrictions to the SALB disease. This will require guidelines on working with these restrictions in order to produce a rubber crop and it also indicates that for this area, rubber tree cultivation has to be based on the use of $P$. ulei resistant material with high productivity. Further field studies must be done to confirm the results of this study.

In addition to genetic breeding for resistance, which provides access to new resistant genotypes, the identification of escape zones is a promising way to boost rubber cultivation in the Americas. Indeed, the resistances are often bypassed in the more or less short term, and cultivation of resistant material in escape zones could delay resistance bypass arrival. However, it will be necessary to monitor these different escape zones over time to ensure the stability of the "escape" trait on time, because the limits of escape zones could also evolve with climate change (Coakley et al., 1999; Cilas et al., 2015).

\section{Acknowledgment}

The authors acknowledge the financial support of the Colombian Institute for Science and Technology (COLCIENCIAS), under the research contract no. 263-2010 and Sarah Bharath for reviewing the English version.

\section{References}

Barrès, B., Carlier, J., Seguin, M., Fenouillet, C., Cilas, C., Ravigné, V., 2012. Understanding the recent colonization history of a plant pathogenic fungus using population genetic tools and Approximate Bayesian Computation. Heredity 109 (5), 269-279.

Campanharo, W.A., Cecilio, R.A., Sperandio, H.V., Jesus Junior, W.C., Pezzopane, J.E., 2011. Modification of the climatic zoning of rubber trees for the Espírito Santo State due to climate change scenarios. Sci. For. 39, 105-116.

Cilas, C., Goebel, F.-R., Babin, R., Avelino, J., 2015. Tropical crop pests and diseases in a climate change setting-a few examples. In: Torquebiau, E. (Ed.), Climate Change and Agriculture Worldwide. Springer, Netherlands, pp. 73-82.

Coakley, S.M., Scherm, H., Chakraborty, S., 1999. Climate change and plant disease management. Annu. Rev. Phytopathol. 37 (1), 399-426.

da Hora Jr., B.T., de Macedo, D.M., Barreto, R.W., Evans, H.C., Mattos, C.R.R. Maffia, L.A., Mizubuti, E.S., 2014. Erasing the past: a new identity for the Damoclean pathogen causing South American leaf blight of rubber. PLoS One 9 (8), e104750. http://dx.doi.org/10.1371/journal.pone.0104750.

da Silva, K. Cecilio, R. Xavier, A., Pezzopane, J., Garcia, G., 2013. Soil and climatic zoning of rubber tree at state of Espírito Santo, Brazil. Irriga 18 (1), 1-12.

da Silva, L.G., 2007. Zoneamento do risco de occorência do mal das folhas da seringueira com base em sistemas de informações geográficas. Tese de Mestrado. Universidade Federal de Viçosa, Viçosa.

de Camargo, Â., de Camargo, M., 2008. Aptidão climática da heveicultura no Brasil. In: Alvarenga, A., do Carmo, C. (Eds.), Seringueira, pp. 25-48.

do Carmo, C., Lumbreras, J., Naime, U., Gonçalves, A., Fidalgo, E., Ágilo, M., Lima, J. 2004. Aspectos culturais e zoneamento da seringueira no estado do Rio de Janeiro. Embrapa Solos, Rio de Janeiro, Brasil.

Gasparotto, L., Ferreira, F., dos Santos, A., Pereira, J., Furtado, E., 2012. Doenças das folhas. In: Gasparotto, L., Pereira, J.C. (Eds.), Doenças da seringueira no Brasil. Embrapa, Brasilia DF, Brasil, pp. 36-176.

Le Guen, V., Garcia, D., Doaré, F., Mattos, C., Condina, V., Couturier, C., et al., 2011 A rubber tree's durable resistance to Microcyclus ulei is conferred by a qualitative gene and a major quantitative resistance factor. Tree Genet. Genomes 7, $877-889$.

Ortolani, A., 1986. Agroclimatologia e o cultivo da seringueira. In: 1. Simposio sobre a Cultura da Seringueira no Estado de Sao Paulo, Piracicaba. Fundação Cargill, pp. $11-32$.

Ortolani, A., Pedro, J., Alfonsi, R., Camargo, M., Brunini, O., 1983. Aptidão agroclimática para regionalização da heveicultura no Brazil. In: Anais (Ed.), Seminário Brasileiro para recomendações de clones de Seringueira. EMBRAPA SUBHEVEA, Brasília, pp. 19-28.

Pinheiro, E., Pinheiro, V., 2008. Heveicultura em área de escape. Seringueira, pp. 85-126.

Rivano, F., Martinez, M., Cevallos, V., Cilas, C., 2010. Assessing resistance of rubber tree clones to Microcyclus ulei in large-scale clone trials in Ecuador: a less timeconsuming field method. Eur. J. Plant Pathol. 126, 541-552.

Rivano, F., Maldonado, L., Simbaña, B., Lucero, R., Gohet, E., Cevallos, V., Yugcha, T., 2015. Suitable rubber growing in Ecuador: an approach to South American leaf blight. Ind. Crop. Prod. 66, 262-270.

Thornthwaite, C.W., 1948. An approach toward a rational classification of climate. Geogr. Rev. 38, 55-94.

Thornthwaite, C.W., Mather, J.R., 1955. The Water Balance. Publications in Climatology. Drexel Institute of Technology, New Jersey, 104 p.

Zong, D.H., Xuequim, Z., 1983. Rubber Cultivation in China. Kuala Lumpur: Proceedings. 